\title{
Praktiske færdigheder i professionsrettede sundhedsuddannelser
}

Carsten Nielsen, lektor, VIA University College, Sygeplejerskeuddannelsen i Aarhus.

Britta Stenholt, lektor, VIA University College, Sygeplejerskeuddannelsen i Silkeborg.

Kirsten Lomborg, professor, Aarhus Universitet, Institut for Klinisk Medicin og Institut for Folkesundhed, Sektion for Sygepleje.

Ida Torunn Bjørk, professor, Oslo Universitet, Afdeling for sygeplejevidenskab.

\section{Reviewet artikel}

Artiklen har fokus på, hvordan læring af praktiske færdigheder kan understøttes og evalueres. Forfatterne er i forbindelse med en litteraturgennemgang blevet opmærksomme på, at der $i$ såvel sygeplejerskeuddannelsen som i lxgeuddannelsen arbejdes med at skxrpe et analytisk perspektiv på og finde systematiske metoder, som kan give støtte til læring og evaluering af praktiske frerdigheder.

Artiklen argumenterer for potentialerne $i$ at udvikle et såkaldt globalt vejlednings- og evalueringsinstrument, der er knyttet til læring af praktiske fardigheder. Et globalt instrument er kendetegnet ved at vare generisk (kan anvendes til forskellige praktiske procedurer), holistisk (inddrager såvel humanistiske som proceduremæssige og tekniske elementer), multiprofessionelt ( $k a n$ anvendes af forskellige professioner), multigraderet (kan anvendes af såvel novicer som erfarne praktikere) og multimodalt (kan anvendes i forskellige kontekster).

I artiklen præsenteres og diskuteres potentialerne i to globale instrumenter eller modeller til læring og evaluering af praktiske færdigheder. De to modeller er The Leicester Clinical Procedure Assessment Tool og Model for praktisk færdighedsudøvelse.

Med artiklen vil vi gerne invitere til fagdidaktiske drøftelser med andre universiteter og professionshøjskoler om at videreudvikle globale undervisnings- og evalueringsinstrumenter. Bag dette ligger også et ønske om at få en dybere indsigt $i$ de praktiske handlingers natur. Målet med at udvikle et globalt vejlednings- og evalueringsredskab er at styrke de studerendes kompetencer til at udfore praktiske handlinger med kvalitet samt at give dem redskaber til at tilegne sig nye praktiske færdigheder i deres fremtidige karriere. 


\section{Læring og evaluering af praktiske færdigheder}

I forskellige sundhedsuddannelser som fx læge-, tandlæge-, sygeplejerske-, jordemoder-, bioanalytiker-, ergoterapeut- og fysioterapeutuddannelsen skal de studerende lære, hvordan de udfører praktiske handlinger hos patienter. Praktisk handlekompetence har betydning for, at den færdiguddannede kan opnå professionel sikkerhed og dermed drage omsorg for patienternes sikkerhed og velvære.

De studerende i sundhedsuddannelserne skal i løbet af deres uddannelse opnå handlekompetence i forhold til udvalgte praktiske handlinger, som professionen på et givet tidspunkt og på en given uddannelsesinstitution anser som centrale i professionsudøvelsen. Eksempler på praktiske handlinger i sundhedsprofessioner kan være rensning og syning af sår, anlæggelse af perifert venekateter og mobilisering af en nyopereret patient. Ud over de udvalgte handlinger vil de studerende stifte bekendtskab med mere specialiserede handlinger i forbindelse med praktik.

Omfanget af praktisk færdighedsudøvelse i sundhedsuddannelserne har der været forskellige traditioner for, og det har varieret over tid inden for enkelte uddannelser. Den vigtigste arena for at lære praktiske færdigheder er klinisk praksis, men vilkårene for at lære praktiske færdigheder er ikke altid optimale i et travlt og specialiseret sundhedsvæsen (Wichmann-Hansen, 2004). Skills lab har fået en større betydning i mange sundhedsuddannelser, både på grund af sundhedsvæsenets forandringer, men også fordi de studerende her kan træne praktiske færdigheder, uden at det får direkte konsekvenser for patienter (Høyer, 2008).

\section{Objective Structured Clinical Evaluation (OSCE)}

Især i medicinstudiet, men også i sygeplejestudiet, har man internationalt siden 70 'erne interesseret sig for summative evalueringer af studerendes kliniske færdigheder i skills lab med anvendelse af Objective Structured Clinical Evaluation (OSCE) (Barratt, 2010; Jones, Pegram, \& Fordham-Clarke, 2010). På flere universiteter i Danmark har OSCE fundet indpas ved medicinstudiet hvorimod den ikke anvendes i sygeplejerskeuddannelsen (Eriksen, 2006).

Der arbejdes fortsat med udvikling af OSCE herunder ikke mindst med metoder, der kan kvalificere den summative evaluering af studerendes handlekompetence (Jones, Pegram, \& Fordham-Clarke, 2010; McKinley et al., 2008; Tolley, Marks-Maran, \& Burke, 2010). Spørgsmålet er, om det er hensigtsmæssigt at fortsætte ad denne vej? Kritikerne af OSCE fremhæver blandt andet, at OSCE er en omstændelig og omkostningstung metode, da der skal beskrives detaljerede kvalitetskriterier for enhver handlingstype, der inddrages i curriculum. McKinley et al. udtrykker tvivl om bæredygtigheden i at fortsætte den omfattende liste af procedurespecifikke beskrivelser som en del af OSCE. En anden kritik af OSCE er, at metoden kun kan anvendes i simulerede omgivelser og ikke viser, hvad den studerende kan i autentiske kliniske 
situationer med den kompleksitet, disse indeholder (Holm \& Aspegren, 2004; McKinley et al., 2008). Kritikerne peger desuden på behovet for at udvikle mindre komplekse og mere autentiske kompetencemålinger, der kan anvendes på tværs af forskellige procedurer og i forskellige kontekster (McKinley et al., 2008). Flere har arbejdet på at udvikle lærings- og evalueringsinstrumenter, der også kan anvendes i klinisk praksis, men disse er typisk rettet mod bredere kliniske kompetencer (Kneebone et al., 2006; Levett-Jones, Gersbach, Arthur, \& Roche, 2010; McKinley et al., 2008; Öhlén \& Erixon, 2005).

\section{Alternativer til OSCE}

Som beskrevet ovenfor er McKinley et al. skeptiske over for OSCE, dels på grund at de praktiske og ressourcemæssige udfordringer denne metode giver og dels på grund af den svage relation til klinisk praksis. Forskergruppen har arbejdet på at udvikle en alternativ metode til evaluering af studerendes praktiske færdigheder, som skal overkomme nogle af de beskrevne begrænsninger ved OSCE. De introducerer begrebet 'et globalt instrument', som indebærer at instrumentet skal være:

- generisk, dvs. kan anvendes til mange kliniske procedurer.

- holistisk, dvs. kan vurdere humanistiske såvel som proceduremæssige og tekniske aspekter af en handling.

- multiprofessionelt, dvs. kan anvendes af forskellige professioner.

- multigraderet, dvs. kan anvendes både til novicer og erfarne praktikere.

- multimodalt, dvs. kan anvendes i forskellige kontekster herunder såvel i skills lab som i klinisk praksis (McKinley et al., 2008).

Vi har i sygeplejeprofessionen og sygeplejerskeuddannelsen gennem en årrække arbejdet med et lærings- og evalueringsredskab, som vi mener lever op til kravene til et globalt instrument (McKinley et al., 2008), selv om vi først ved et litteraturreview (Stenholt, 2011) blev opmærksomme på begrebet og dets indhold. Den eneste kilde, der havde bud på et globalt instrument i forhold til praktiske færdigheder, var McKinley et al. (2008).

\section{Hensigt med artiklen}

Vi deler intentionen hos McKinley et al. (2008) om at udvikle et håndterbart læringsog evalueringsinstrument, som ikke bare kan anvendes i skills lab men også i klinisk praksis, herunder et instrument, som studerende selv og deres vejledere i klinikken kan anvende. I det følgende vil vi sammenligne to globale instrumenter til læring og evaluering af praktiske færdigheder i sundhedsuddannelser og diskutere deres styrker og svagheder. Afslutningsvis vil vi diskutere potentialerne i at arbejde med globale lærings- og evalueringsredskaber rettet mod praktiske færdigheder i sundhedsprofessionerne. De to instrumenter er henholdsvis The Leicester Clinical Procedure Assessment Tool (LCAT) (McKinley et al., 2008) og Model for praktisk frordighedsudøvelse (Bjørk, 1999; Bjørk \& Kirkevold, 2000). 
Da vi ikke forventer, at læserne er bekendte med de to instrumenter, vil vi indledningsvis præsentere disse.

\section{The Leicester Clinical Procedure Assessment Tool (LCAT)}

Grundstrukturen i LCAT blev skabt gennem analyse af publicerede tjeklister til vurdering af praktiske færdigheder. Første udgave af evalueringsinstrumentet blev ved denne analyse drøftet $i$ et fokusgruppeinterview med deltagelse af kliniske eksperter. På bagrund af drøftelserne i fokusgruppeinterviewet blev instrumentet kvalificeret og efterfølgende afprøvet hos grupper af medicinstuderende i skills lab. Afsluttende blev instrumentet testet gennem et bredt Delphi-studium blandt undervisere, hvor deltagerne svarede på et udsendt spørgeskema om vurderingsskemaet (McKinley et al., 2008).

Ambitionen var at udvikle et globalt vurderingsredskab, der blandt andet kunne anvendes på tværs af procedurer og i forskellige kontekster, herunder såvel skills lab som klinisk praksis. LCAT består af 5 overordnede kategorier som hver yderligere beskrives med mellem 4 - 12 elementer, som bør indgå i handlingen og følge faglige forskrifter (Tabel 1).

Tabel 1. Category and constituent components $i$ LCAT*

\begin{tabular}{|l|l|}
\hline Categories & Elements \\
\hline the patient & $\begin{array}{l}\text { Introduces self to patient and/or his or her family } \\
\text { Shares information about the procedure appropriately } \\
\text { Listens attentively } \\
\text { Answers questions honestly } \\
\text { Checks patient's understanding } \\
\text { Obtains valid and continuing consent } \\
\text { Works with the patient to maintain co-operation } \\
\text { Use of communication skills } \\
\text { Performs procedure in a compassionate and patient- } \\
\text { centered manner }\end{array}$ \\
\hline Safety & $\begin{array}{l}\text { Checks patients identity correctly } \\
\text { Checks/completes request and/or documentation cor- } \\
\text { rectly } \\
\text { Labels sambles/printouts correctly } \\
\text { Applies procedure-specific safety measures correctly } \\
\text { Is aware of limitations of personal competence and role, } \\
\text { and acts appropriately } \\
\text { Maximises own and others' safety } \\
\text { Offers appropriate post-procedure care to the patient }\end{array}$ \\
\hline
\end{tabular}




\begin{tabular}{|c|c|c|}
\hline & Infection prevention & $\begin{array}{l}\text { Washes and/or decontaminates hands } \\
\text { Prepares patient's skin appropriately } \\
\text { Uses anti-infection barriers as required } \\
\text { Displays appropriate practice of aseptic technique } \\
\text { Disposes of waste appropriately } \\
\text { Optimises infection prevention within environmental } \\
\text { limitations }\end{array}$ \\
\hline 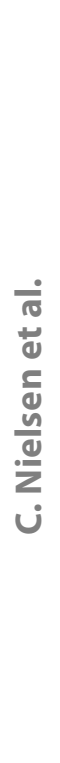 & Procedural competence & $\begin{array}{l}\text { Assesses the patient appropriately } \\
\text { Appropriately assesses the indications for and contra- } \\
\text { indications to the proposed procedure } \\
\text { Plans the procedure with respect to patient factors } \\
\text { Prepares the patient appropriately } \\
\text { Select and checks equipment, disposables and consum- } \\
\text { ables } \\
\text { Performs procedure fluently } \\
\text { Displays familiarity with equipment } \\
\text { Displays knowledge of the procedure } \\
\text { Uses assistance appropriately } \\
\text { Handles samples/ensures quality control og outputs } \\
\text { correctly } \\
\text { Deals appropriately and sensitively with the involving } \\
\text { situation } \\
\text { Demonstrates respect for tissue }\end{array}$ \\
\hline 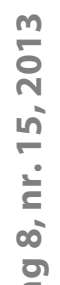 & Team-working & $\begin{array}{l}\text { Displays understanding and respect for the roles of the } \\
\text { team members } \\
\text { Communicates effectively with the team } \\
\text { Leaves clinical area clean and tidy } \\
\text { Documents procedure correctly }\end{array}$ \\
\hline
\end{tabular}

* Teksten er en gengivelse af McKinley et al. (2008). For at undgå muligheden for fejloversættelser af kategorier og elementer i LCAT har vi valgt at bruge de engelske begreber.

\section{Model for praktisk færdighedsudøvelse}

Model for praktisk færdighedsudøvelse blev oprindeligt udviklet i et forskningsarbejde med fokus på nyuddannede sygeplejerskers udvikling af deres kompetence til at udføre praktiske sygeplejehandlinger (Bjørk, 1999; Bjørk \& Kirkevold, 2000). Modellen blev udviklet på baggrund af teoretiske studier og empiriske undersøgelser af fællestræk ved forskellige typer af praktiske sygeplejehandlinger (Figur 1). Modellen blev efterfølgende anvendt til undersøgelse af nyuddannede sygeplejersker kompetenceudvikling. Modellen er illustreret som en cirkel bestående af 6 kategorier der tilsammen udgør det centrale i en praktisk færdighed. Cirkelformen illustrerer at modellen ikke er hierarkisk og de stiplede linjer viser kategoriernes indbyrdes sammenhæng. Pilene henviser til, at omsorgsfuld væremåde har indflydelse på alle kategorier. I enhver handling er alle kategorier i spil. 
Andre sygeplejeforskere samt kliniske og teoretiske undervisere i sygeplejerskeuddannelsen blev inspireret af Model for praktisk fxrdighedsudøvelse og har siden 2004 samarbejdet med Bjørk i forskergruppen Research in Nursing Skills (RiNS), hvor fokus er praktisk færdighedsudøvelse i sygepleje. En af ambitionerne i forskergruppen har været at udvikle et globalt lærings- og vurderingsinstrument på baggrund af Model for praktisk færdighedsudøvelse (www.rins.dk).

RiNS-gruppen har arbejdet med at forfine, udvikle og validere et instrumentelt supplement til den originale Model for praktisk færdighedsudøvelse. Hensigten har været, at modellen kan kommunikeres til en bred målgruppe og fungere som et velafgrænset redskab i forskning, undervisning og formativ evaluering af praktisk færdighedsudøvelse. I det instrumentelle supplement til modellen (Tabel 2) forklares de enkelte kategorier i modellen, og der er angivet kvalitetskriterier for god udøvelse af de enkelte kategorier. Der er udviklet karakteristika, som kendetegner kvalitet i hver af de 6 kategorier; tilsammen 21 karakteristika fordelt med $1-8$ elementer i hver kategori.

Det instrumentelle supplement er blevet indholds- og begrebsvalideret. Indholdet er systematisk undersøgt med henblik på at vurdere, om beskrivelsen er dækkende for forskellige typer af praktiske færdigheder. Gennem begrebsvalideringen er det sikret, at det instrumentelle supplement svarer til modellen. Valideringsprocessen blev gennemført i Norge og Danmark i en variation af kliniske kontekster på forskellige sygehuse, plejecentre og skills lab (Møller \& Riemenschneider, 2012; Nielsen, Sommer, Larsen \& Bjørk, 2012).

Da den originale model og det efterfølgende instrumentelle supplement var udviklet på engelsk, blev disse efterfølgende oversat til norsk og dansk, og oversættelserne blev valideret ved en frem-og-tilbageoversættelse mellem sprogene, hvor ord og sætninger blev justeret, indtil der var konsensus mellem de forskellige oversættere og udviklingsgruppen i RiNS om bedste oversættelse.

Figur 1 Model for praktisk færdighedsudøvelse (Bjørk, 1999)

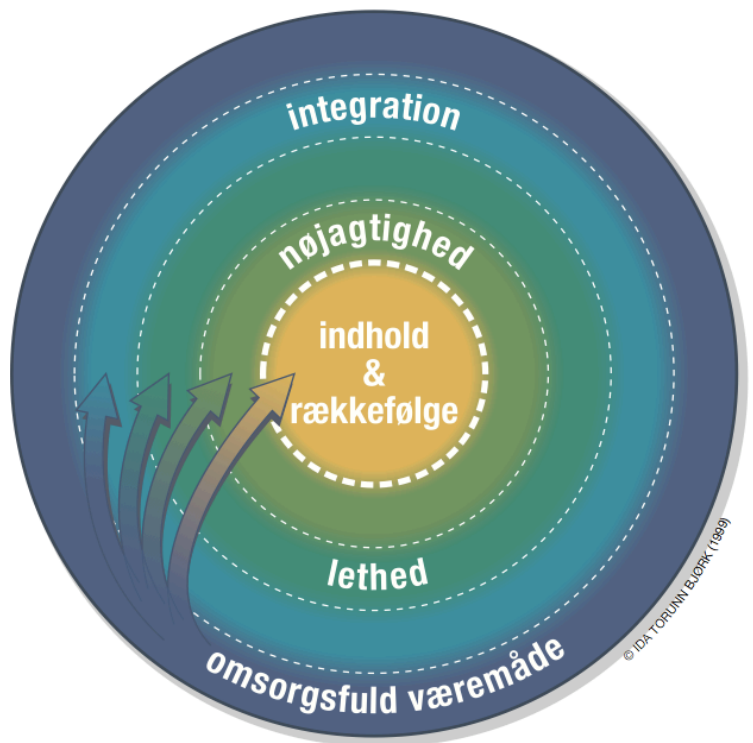


Tabel 2. Instrumentelt supplement til Model for praktisk fardighedsudøvelse.

\begin{tabular}{|c|c|}
\hline Definition af modellens kategorier & Karakteristika ved god udøvelse \\
\hline $\begin{array}{l}\text { Indhold og rækkefølge er kerneaspek- } \\
\text { terne ved en praktisk færdighed. Det } \\
\text { indebærer at de nødvendige trin i } \\
\text { færdigheden er inkluderet og udført i } \\
\text { en logisk rækkefølge. }\end{array}$ & $\begin{array}{l}\text { Indholdet og rækkefølgen bestemmes på grundlag af } \\
\text { kliniske retningslinjer, professionelle standarder og } \\
\text { principper. Indholdet og rækkefølgen tilpasses pati- } \\
\text { enten og situationen. }\end{array}$ \\
\hline $\begin{array}{l}\text { Nøjagtighed betyder præcision i be- } \\
\text { vægelsestrin, instruktion og informa- } \\
\text { tion. Nøjagtighed er vigtig for at op- } \\
\text { retholde sikkerhed for patienten, } \\
\text { sygeplejersken og miljøet. }\end{array}$ & $\begin{array}{l}\text { Nøjagtighed indebærer at handle } \\
-\quad \text { korrekt } \\
\text { - } \text { præcist } \\
\text { Nøjagtighed indebærer at informere og instruere } \\
\text { - } \text { det som er nødvendigt og tilstrækkeligt } \\
\text { - } \text { tydeligt } \\
-\quad \text { forståeligt }\end{array}$ \\
\hline $\begin{array}{l}\text { Lethed betyder at tempo og rytme er } \\
\text { tilpasset både patienten og typen af } \\
\text { praktisk færdighed, og at den prakti- } \\
\text { ske færdighed udføres ubesværet. }\end{array}$ & $\begin{array}{l}\text { Lethed indebærer at handle, informere og instruere } \\
\text { - } \quad \text { uden tøven } \\
\text { - } \quad \text { uden unødvendige ophold }\end{array}$ \\
\hline $\begin{array}{l}\text { Integration betyder at alle parallelle } \\
\text { aspekter i den praktiske færdighed er } \\
\text { samstemt. Integration betyder også, } \\
\text { at færdigheden som helhed er tilpas- } \\
\text { set patientens nuværende tilstand og } \\
\text { situation. }\end{array}$ & $\begin{array}{l}\text { Integration indebærer } \\
-\quad \text { timing og koordinering af handlingens ele- } \\
\text { menter } \\
\text { Integration i forhold til tilpasning indebærer at } \\
\text { - være opmærksom } \\
-\quad \text { have overblik } \\
-\quad \text { være fleksibel }\end{array}$ \\
\hline $\begin{array}{l}\text { Omsorgsfuld væremåde betyder at ska- } \\
\text { be en atmosfære, hvor patientens } \\
\text { værdighed opretholdes, selvbestem- } \\
\text { melse sikres under hensyntagen til } \\
\text { patientens aktuelle situation og vel- } \\
\text { være understøttes. }\end{array}$ & 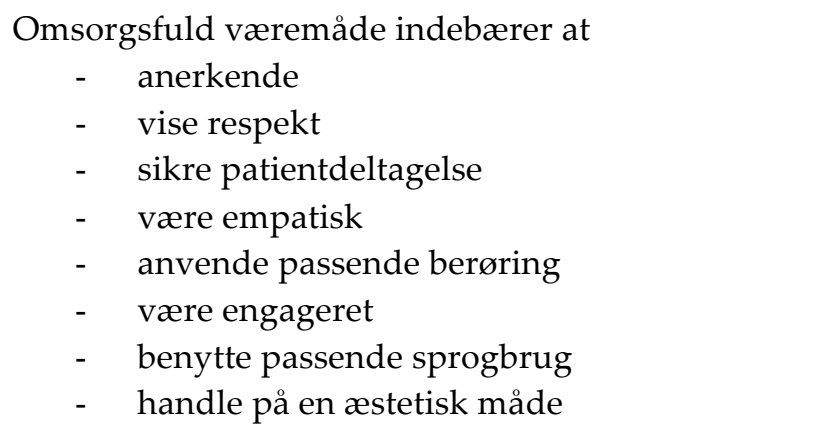 \\
\hline
\end{tabular}

\section{Forskelle og ligheder mellem LCAT og Model for praktisk færdighedsudøvelse}

Vi ser et stort sammenfald mellem intentionerne hos McKinley et al. (2008) med udviklingen af LCAT og intentionerne med videreudvikling af Model for praktisk fxrdighedsudøvelse til et vejlednings- og evalueringsinstrument. De er begge et forsøg på at udvikle et globalt instrument, der stiler mod at være generisk, holistisk, multiprofessionelt, multigraderet og multimodalt. 
Der er store ligheder mellem de to modeller men også forskelle. Begge modeller lægger vægt på selve den processuelle kompetence og tilpasningen af handlingen til den konkrete patient. Ligeledes lægger begge modeller vægt på det patientcentrerede og de kommunikative aspekter knyttet til handlingen, men det er forskelligt, hvordan aspekterne vægtes, og hvor eksplicit aspekterne er med i modellen som hovedkategorier eller som underelementer eller karakteristika ved god udøvelse.

I tabellen nedenfor (Tabel 3) er hovedkategorierne i de to modeller sammenlignet og kommenteret.

Tabel 3. Sammenligning af LCAT og Model for praktisk færdighedsudøvelse

\begin{tabular}{|l|l|l|}
\hline LCAT & $\begin{array}{l}\text { Model for praktisk } \\
\text { færdighedsudøvelse }\end{array}$ & Kommentarer \\
\hline $\begin{array}{l}\text { Communication } \\
\text { and working with } \\
\text { the patient }\end{array}$ & $\begin{array}{l}\text { Omsorgsfuld } \\
\text { væremåde }\end{array}$ & $\begin{array}{l}\text { De to kategorier har noget til fælles, men i Model } \\
\text { for praktisk fardighedsudøvelse er vægtningen på det } \\
\text { relationelle og etiske. } \\
\text { I Model for praktisk færdighedsudøvelse indgår kom- } \\
\text { munikation og samarbejde både som en del af } \\
\text { nøjagtighed og integration. } \\
\text { I LCAT forekommer de relationelle og etiske ele- } \\
\text { menter i flere kategorier. Eksempelvis at svare } \\
\text { ærligt på spørgsmål under kategorien communica- } \\
\text { tion and working with the patient, og at planlægge } \\
\text { handlingen med respekt for patienten og at forbe- } \\
\text { rede patienten hensigtsmæssigt under kategorien } \\
\text { procedural competence. }\end{array}$ \\
\hline Safety & Nøjagtighed & $\begin{array}{l}\text { LCAT har en egen kategori til sikkerhedsaspektet } \\
\text { herunder sikkerhed for patient og fagperson samt } \\
\text { dokumentation. I Model for praktisk færdighedsudø- } \\
\text { velse beskrives nøjagtighed i forhold til bevægelses- } \\
\text { trin, instruktion og information for at skabe sik- } \\
\text { kerhed for patient, fagperson og miljø. Begge mo- } \\
\text { deller henviser til at gældende retningslinjer skal } \\
\text { følges. }\end{array}$ \\
\hline Infection \\
& & $\begin{array}{l}\text { Beskrives ikke som en selvstændig kategori i Mo- } \\
\text { del for praktisk færdighedsudøvelse, men indgår som } \\
\text { et element under nøjagtighed og er en del at sik- } \\
\text { kerhedsaspektet. Ved at følge procedurebeskri- } \\
\text { velser fokuseres der på sikkerhed og forebyggelse } \\
\text { af infektion. Fx er procedurer som sårpleje og an- } \\
\text { læggelse af blærekateter domineret af forebyg- } \\
\text { gende principper. }\end{array}$ \\
\hline
\end{tabular}




\begin{tabular}{|c|c|c|}
\hline $\begin{array}{l}\text { Procedural } \\
\text { competence }\end{array}$ & Indhold og rækkefølge & $\begin{array}{l}\text { Der er stor lighed i disse kategorier. Procedural } \\
\text { competence beskrives med } 12 \text { delelementer i LCAT, } \\
\text { og som et kerneaspekt i en praktisk færdighed i } \\
\text { indhold og rækkefølge i Model for praktisk færdigheds- } \\
\text { udøvelse. }\end{array}$ \\
\hline Team-working & & Indgår ikke i Model for praktisk fxrdighedsudøvelse. \\
\hline & Lethed & $\begin{array}{l}\text { Indgår ikke eksplicit i LCAT som en selvstændig } \\
\text { kategori, men elementer under procedural compe- } \\
\text { tence beskriver, at den professionelle "performs } \\
\text { procedure fluently". }\end{array}$ \\
\hline & Integration & $\begin{array}{l}\text { Indgår ikke eksplicit i } L C A T \text {, men timing og koor- } \\
\text { dinering kan være dele af procedural competence. } \\
\text { Tilpasning af handlingen til den aktuelle patients } \\
\text { tilstand og situation indgår ikke eksplicit i } L C A T \text {, } \\
\text { men synes at være en del af kategorien communi- } \\
\text { cation and working with the patient, hvor det beskri- } \\
\text { ves, at proceduren skal udføres på "a compassio- } \\
\text { nate and patient-centered manner". }\end{array}$ \\
\hline
\end{tabular}

Forskellen mellem de to modeller synes mest at ligge i, hvilke overordnede kategorier, der er udviklet. Baggrunden for forskellene i de overordnede kategorier kan have sammenhæng med metoden bag udviklingsprocesserne og måske også professionsfaglige og nationale forskelle.

Den proceduremæssige sikkerhed er central i begge modeller, men LCAT underopdeler aspektet betydeligt mere end Model for praktisk frrdighedsudøvelse med kategorierne 'lethed' og 'nøjagtighed' samt med dele af kategorien 'integration'. En central forskel i afgrænsningen af modellerne ses, hvor Model for praktisk færdighedsudøvelse fokuserer på selve den praktiske handling og samarbejdet med patienten, mens LCAT også vægter teamsamarbejde og dokumentation.

Man kan sige, at LCAT med kategorien 'teamwork' anskuer den praktiske handling bredere, idet den inddrager samarbejdet med andre personalemedlemmer, dokumentation af handlingen mv. som del af handlingen. Der kan ikke være tvivl om, at teamwork er væsentligt. Om det skal indgå i en global model for praktiske færdigheder er et spørgsmål om logisk afgrænsning. Det er korrekt, at visse handlinger kræver teamwork, men mange handlinger kan udføres af en enkelt sundhedsprofessionel i samarbejde med patienten. Teamsamarbejde, interdisciplinært samarbejde, dokumentationspraksis og organisationsforståelse er centrale rammefaktorer for at udføre en handling, men kan også anskues som et område, der bygger på en anden referenceramme, og som kræver andre lærings- og evalueringsinstrumenter. 
Begge modeller inddrager sikkerhedsaspektet, fx ved forebyggelse af infektioner og sikkerhed for personale, men det er tydeligt, at disse aspekter har fået en mere fremtrædende plads i LCAT, hvor de udgør overordnede kategorier med beskrivelse af tilhørende delkompetencer. I Model for praktisk færdighedsudøvelse indgår sikkerhedsaspektet og forebyggelse af infektioner i selve procedurebeskrivelsen eller den faglige standard for en given handling og er knyttet til kategorierne 'indhold', 'rækkefølge' og 'nøjagtighed'. Det stærke fokus på sikkerhedsaspektet og forebyggelse af infektion kan efter vores opfattelse flytte fokus i modellen i retning mod invasive procedurer eller procedurer, hvor opmærksomhed på sikkerhedsaspektet er centralt. Model for praktisk færdighedsudøvelse søger at favne alle handlingstyper også dem af ikke invasiv karakter, hvor sikkerhedsaspektet og forebyggelse af infektion er mindre centrale. Hvis en model skal være generisk, skal den efter vores opfattelse netop kunne favne alle forskellige handlingstyper og ikke i sin opbygning favorisere specielle typer.

Kommunikation og samarbejde med patienten er centrale i begge modeller om end de beskrives med nuanceforskelle og placeres lidt forskelligt i instrumenterne. Model for praktisk fxrdighedsudøvelse anvender begrebet patientdeltagelse og appellerer måske mere til den aktive patient. Den udskiller ikke disse elementer som selvstændige kategorier men ser dem som del af selve den praktiske handling. Eksempelvis at patienten instrueres på korrekt vis på det rette tidspunkt. Omvendt gør Model for praktisk fxrdighedsudøvelse mere ud af de relationelle og etiske aspekter i handlingen i den selvstændige kategori 'omsorgsfuld væremåde', selv om disse aspekter også i en vis grad indgår i LCAT i underkategorier til 'kommunikation' og 'samarbejde'.

I kategorien 'integration' i Model for praktisk færdighedsudøvelse lægges der stor vægt på tilpasningen af handlingen til den enkelte patients helbredsmæssige situation, hvilket er svagere betonet i LCAT. Dette er et centralt aspekt i et generisk og holistisk instrument, idet der kan være stor forskel på at udføre samme handling til patienter i forskellige helbredsmæssige eller mentale tilstande. Eksempelvis vil det være forskelligt, hvordan et barn, et ungt stærkt menneske eller en ældre svækket patient skal mobiliseres efter et operativt indgreb.

Generelt er detaljeringen i beskrivelserne i LCAT højere, end det er tilfældet i Model for praktisk færdighedsudøvelse. Ulempen ved mindre detaljerede beskrivelser er, at det kan skabe mulighed for lokale og personlige tolkninger. Omvendt kan den detaljerede beskrivelse i LCAT svække instrumentets generiske sigte. LCAT mister måske noget af det generiske, når det eksempelvis fremhæves, at den professionelle "checks patient's identity correctly" eller "demonstrates respect for tissue". 


\section{Diskussion af instrumenternes anvendelighed i vejledning og evaluering}

LCAT er primært udviklet som et globalt redskab til summativ evaluering af praktiske færdigheder og som et svar på de problemstillinger, forskergruppen ser i OSCEtraditionen. Selv om LCAT kan være et modsvar til udvikling af specifikke evalueringskriterier for hver type handling, kan instrumentet med de 5 overkategorier og 38 underkategorier i sig selv være for omfattende at overskue og operationalisere i en evalueringssituation i skills lab.

Forskergruppen bag LCAT peger på potentialerne i modellen som et redskab i undervisningen og i formativ evaluering, hvilket vi nærmest opfatter som en forudsætning, hvis det skal blive succesfuldt at anvende LCAT som evalueringsinstrument. Det er et anerkendt pædagogisk princip, at der skal være overensstemmelse mellem undervisningens indhold og metode samt undervisningsform og den afprøvning, der anvendes ved afslutning af et studieforløb (Biggs \& Tang, 2011). Derfor må LCAT efter vores opfattelse inddrages som et vejlednings- og læringsredskab, hvis den skal være pædagogisk meningsfuld at bruge som evalueringsinstrument. Ligeledes ser vi det som et naturlig aspekt, at instrumentet ikke alene anvendes i skills lab men også i vejledning og læring under kliniske studier. Sidstnævnte vil kræve, at vejlederne i klinikken også bliver fortrolige med instrumentet, og her kan et instrument med 5 overordnede kategorier og 38 underkategorier være ganske svær at anvende. I vores afprøvninger af Model for praktisk frrdighedsudøvelse kan vi konstatere, at kliniske vejledere og studerende skal bruge en del tid og engagement for at blive fortrolige med de 6 kategorier og 21 karakteristika for kvalitet, så disse kan bruges som et indarbejdet lærings-, vejlednings- og formativt evalueringsinstrument under de kliniske studier (Nielsen et al., 2013; Reierson et al., 2013). Det kan lykkes at blive fortrolig med kategorier og karakteristika og vi kan konstatere, at såvel studerende som kliniske vejleder finder, at instrumentet er en værdifuld støtte i vejlednings- og læreprocessen. Modellen gør det lettere for de kliniske vejledere at give feedback til de studerende. De studerende oplever, at evalueringskriterierne er blevet eksplicitte, hvilket de sætter pris på (Nielsen et al., 2013).

Der er foreløbig gennemført to studier af anvendelse af Model for praktisk fxrdighedsudøvelse i skills lab, som peger på, at modellen også har potentialer når den anvendes i denne kontekst (Reierson et al., 2013; Møller \& Riemenschneider, 2012).

\section{Erfaringer med brug af Model for praktisk færdighedsudøvelse i klinisk vejled- ning}

De kliniske vejledere beskriver, at kategorierne i modellen på en dækkende måde indfanger det centrale i praktisk færdighedsudøvelse (holistisk), og de udtrykker tilfredshed ved at have fået et begrebsapparat om praktiske færdigheder, som de ikke tidligere har haft. Modellen kan bruges på tværs af forskellige procedurer (ge- 
nerisk) og i forskellige kontekster (multimodal). Såvel erfarne sygeplejersker som sygeplejestuderende kan anvende modellen (multigraderet). Der er ikke foretaget undersøgelser af, om andre sundhedsprofessioner kan bruge modellen (multiprofessionel), men ved præsentation af modellen for læger og terapeutgrupper, giver disse faggrupper udtryk for, at den også giver mening for dem.

Fokus i afprøvningen har været på modellens anvendelse som støtte i de studerendes læreproces. Erfaringen er, at modellen kan anvendes i en sekvensering af læringsbestræbelserne, hvor studerende kan arbejde med enkeltkomponenter i modellen og modtage formativ evaluering i forhold til disse. Det vil for nybegynderen typisk være elementerne 'indhold', 'rækkefølge' og 'nøjagtighed', der først er fokus på. Med øvelse kan den studerende få 'lethed' i handlingen og overskud til at få øget fokus på de mere situationsbundne kategorier 'integration' og 'omsorgsfuld væremåde'. Modellen tydeliggør kompleksiteten i handlingen for de studerende men giver dem også muligheder for at arbejde med trinvis mestring af denne kompleksitet.

Modellen har medvirket til at flytte opmærksomheden fra ensidig træning af 'indhold' og 'rækkefølge' knyttet til specifikke procedurer til at anskue praktiske færdigheder bredere med inddragelse af de øvrige elementer i modellen. Med anvendelse af modellen kan man som vejleder gøre den studerende opmærksom på delkomponenter i en handling, som kan overføres fra en procedure til en anden. Det helt centrale i modellen synes at være den øgede opmærksomhed på det patientbundne og situationsorienterede i handlingen og tilpasningen af den praktiske handling hertil.

\section{Samarbejde om udvikling af globale vejlednings- og evalueringsredskaber}

Vi vil gerne invitere til et samarbejde med andre forsknings- og uddannelsesinstitutioner om at videreudvikle globale undervisnings- og evalueringsinstrumenter og derigennem styrke indsigten i de praktiske handlingers natur, samt hvordan vi bedst lærer studerende at udføre praktiske handlinger med kvalitet.

Den nordiske netværksgruppe Research in Nursing Skills har fokus på at teste og validere redskaber, der kan styrke de studerendes læring af praktiske færdigheder. Vi vil som gruppen bag LCAT gerne udvikle et summativt evalueringsredskab på baggrund af Model for praktisk fxrdighedsudøvelse og ser potentialer i at samarbejde med andre underviser- og forskergrupper om disse udfordringer.

Carsten Nielsen, lektor, VIA University College Sygeplejerskeuddannelsen i Aarhus. Uddannelseskoordinator med fokus på curriculumudvikling, implementering og evaluering.

Britta Stenholt, lektor, VIA University College Sygeplejerskeuddannelsen i Silkeborg. Underviser i sygeplejerskeuddannelsen.

Kirsten Lomborg, professor, Aarhus Universitet, Institut for Klinisk Medicin og Institut for Folkesundhed, Sektion for Sygepleje. Forsker i patientinvolvering. 
Ida Torunn Bjørk, professor, Oslo Universitet, Afdeling for sygeplejevidenskab. Forsker i klinisk sygepleje med fokus på praktiske fardigheder og læring af praktiske fxrdigheder.

Alle forfattere er medlemmer af forskningsnetwærket Research in Nursing Skills, med særligt fokus på forskning $i$ kliniske færdigheder $i$ sygepleje og læring af kliniske færdigheder. For yderligere information se www.rins.dk

\section{Litteratur}

Barratt, J. (2010). A focus group study of the use of video-recorded simulated objective structured clinical examinations in nurse practitioner education. Nurse Education in Practice, 10(3), 170-175.

Biggs, J. \& Tang, C. (2011). Teaching for quality learning at university. Maidenhead: McGraw-Hill and Open University Press.

Bjørk, I. T. (1999). Hands-on Nursing: New Graduates' Practical Skill Development in the Clinical Setting. Doctoral thesis, Institute of Nursing Science, University of Oslo, Norway.

Bjørk, I. T. \& Kirkevold, M. (2000). From simplicity to complexity: Developing a model of practical skill performance in nursing. Journal of Clinical Nursing, 9(4), 620-631.

Eriksen, P., Gade, H., Maglekjær, K. M., Mortensen, S., Nielsen, H., Riis, H. \& Winnem, G. (2006). Kliniske prøveformer. Sammenfattende rapport. Sygeplejeskolen i Vejle Amt.

Holm, A. L. \& Aspegren, K. (2004). Objective structured clinical examination--an established method of testing physicians' clinical competence. Ugeskrift for Læger, 166(21), 2002-2004.

Høyer, C. S. (2008). Feedback og debriefing. Dansk Universitetspædagogisk Tidsskrift, 3(6), 3-9.

Jones, A., Pegram, A. \& Fordham-Clarke, C. (2010). Developing and examination an objective structured clinical examination. Nurse Education Today, 30(2), 137-414.

Kneebone, R., Nestel, D., Yadollahi, F., Brown, R., Nolan, C., Durack, J. \& Darzi, A. (2006). Assessing procedural skills in context: Exploring the feasibility of an integrated procedural performance instrument (IPPI). Medical Education, 40(11), 1105-1114.

Levett-Jones, T., Gersbach, J., Arthur, C. \& Roche, J. (2011). Implementing a clinical competency assessment model that promotes critical reflection and ensures nursing graduates' readiness for professional practice. Nurse Education in Practice 11(1), 64-69.

McKinley, R. K., Strand, J., Gray, T., Schuwirth, L., Alun-Jones, T. \& Miller, H. (2008). Development of a tool to support holistic generic assessment of clinical procedure skills. Medical Education, 42(6), 619-627.

Møller, E. \& Riemenschneider, A. W. (2012). Sådan læres praktiske færdigheder i færdighedslaboratorium. Sygeplejersken, 112(11), 78-82. 
Nielsen, C., Sommer, I., Larsen, K. \& Bjørk, I. T. (2013). Model of practical skill performance as an instrument for supervision and formative assessment. Nurse Education in Practice. 13(3), 176-180.

Öhlén, J. \& Erixon, G. (2005). An assessment tool for clinical nursing education. Nordic Journal of Nursing Research \& Clinical Studies/Vård i Norden, 25(3), 61-67.

Reierson, I. Å., Hvidsten, A., Wighus, M., Brungot, S. \& Bjørk, I. T. Key issues and challenges in developing a pedagogical intervention in the clinical skills centre - an action research study. In press April 302013 in Nurse Education Today.

Stenholt B. (2011). Litteraturstudie. Modeller, systemer eller instrumenter til at lære og evaluere praktiske færdigheder i forbindelse med klinisk udøvelse. RiNS 2011 (Upubliceret rapport).

Tolley, K., Marks-Maran, D. \& Burke, L. (2010). The snapshot tool: A new form of practice assessment. British Journal of Nursing, 19(14), 905-911.

Wichmann-Hansen, G. (2004). Praktik i lægeuddannelsen: Et kvalitativt studie om læring og vejledning i klinikken. Ph.d.-afhandling. Det Sundhedsvidenskabelige Fakultet, Aarhus Universitet.

www.rins.dk 